\title{
Women Singer-Songwriters as Exemplary Actors: The Music of Rape and Domestic Violence
}

\author{
KATHANNE W. GREENE
}

At the 2016 Oscars, Lady Gaga, joined onstage by fifty rape survivors, performed the song "Til It Happens to You." The Oscar-nominated song by Lady Gaga and Diane Warren was written for The Hunting Ground, a documentary film about campus sexual assault. Over thirty-one million people viewed the Oscar performance, which brought some in the audience to tears, and the video on Vevo has received over twenty-nine million views with another twenty-eight million views on YouTube. The film, video, and performance are the result of a growing political and social movement by young high school and college women to force schools, universities, and colleges to vigorously respond to rape and sexual harassment on campus. In response to complaints filed by more and more young women, the Obama Administration and the Office of Civil Rights (OCR) in the Department Education began investigating claims that schools, colleges, and universities were not actively and adequately responding to claims of sexual assault and harassment despite passage of the Clery Act of 1990. The Clery Act requires colleges and universities to report data on crime on campus, provide support and accommodations to survivors, and establish written policies and procedures for the handling of campus crime. ${ }^{1}$ Since 2011, the OCR has expanded its efforts to address sexual assault on campuses as violations of Title IX of the Education Amendments of 1972 that prohibits sex discrimination in educational programs or activities that receive federal funds. ${ }^{2}$

With twenty years between the creation of the first domestic violence shelters and rape crisis centers and the passage of the Violence Against Women Act (1994) and forty years between the beginnings of the movements and Lady Gaga's performance before a worldwide audience, the anti-rape and anti-domestic violence movements, like the women's rights movement, have experienced waves of activism and optimism followed by bureaucratization and backlash and at times a degree of immobilization. Meanwhile, women singer-songwriters have increasingly accessed popular music, and in the words of Eyerman and Jamison, have served as exemplary actors, carrying the message of the movements into wider popular culture. ${ }^{3}$ Thus, while the political movements sputtered, socially, Americans were still increasingly becoming aware of the issues of rape and domestic violence.

\section{Music and Social and Political Movements}

Eyerman and Jamison argue in Music and Social Movements: Mobilizing Traditions in the Twentieth Century that the relationship between music and social movements is not simply functional (the

\footnotetext{
${ }^{1}$ Clery Center, "Summary of the Jeanne Clery Act," accessed June 24, 2016, https://clerycenter.org/summary-jeanne-cleryact.

${ }^{2}$ Russlyn Ali, “Dear Colleague Letter: Sexual Violence,” U. S. Department of Education Office of Civil Rights, April 4, 2011.

${ }^{3}$ Ron Eyerman and Andrew Jamison, Music and Social Movements: Mobilizing Traditions in the Twentieth Century (Cambridge: Cambridge University Press), 1998.
} 
establishment of identity, solidarity, and mobilization), but also involves a mediational process between culture and politics:

Social movements are potential sites of emergent cultural formations. They provide spaces where aspects of residual subcultures can be transformed into forces for social and cultural transformation. ${ }^{4}$

Social movements present and represent alternatives. Social movements transform marginal subcultures into real alternatives by offering visions and models of alternative forms of meaning and identity which can be consciously chosen. ${ }^{5}$

One of those spaces where alternative forms of meaning and identity can be articulated is music.

In addition, Eyerman and Jamison note that in many social movements the "concern is to change values rather than particular political results... Social movements are seen as being formed within and, in turn, helping to re-form broader dimensions of social life." to be directed toward a specific political goal, but may be instead designed to exemplify alternative values and meanings which will lead to social transformation. Eyerman and Jamison note that that the feminist movement today seems more concerned with cultural transformation than political results. It is through the movement intellectuals "that culture and politics are creatively combined to produce social change." These movement intellectuals use what Eyerman and Jamison call "exemplary action" to express the meaning of the movement. ${ }^{7}$ Yet, movement intellectuals are not necessarily the leaders of the movements. They can also be artists, writers and musicians. For example, Eyerman and Jamison consider Paul Robeson, Woody Guthrie, Pete Seeger, Bob Dylan, Phil Ochs, Joan Baez, and Bruce Springsteen to be exemplary actors. Music (and art and literature), to the extent that it becomes a source of empowerment, education, and consciousness-raising, can serve as exemplary social action. ${ }^{8}$ In addition, music must play a truth-bearing role that Eyerman and Jamison note can only occur in the context of a social movement. Indeed, for the music to be exemplary, it must be both truth-bearing and emotive ${ }^{9}$. These exemplary actions can also serve to maintain a movement "even when it no longer has a visible presence in the form of organizations, leaders, and demonstrations, and can be a vital force in preparing the emergence of a new movement." 10

This research will explore and expand on Eyerman and Jamison's exemplary action in the context of music dealing with rape and domestic violence as written and performed by five women singersongwriters (Joni Mitchell, Tracy Chapman, Tori Amos, Ani DiFranco, and Lady Gaga). Neither the antirape or anti-domestic violence movements relied upon music as a source of identity, solidarity, or mobilization, yet their existence opened a space for musicians, especially women singer-songwriters, to empower, educate and raise the consciousness of women and men-that is, to engage in exemplary actions around the issues of rape and domestic violence. As these movements were transformed through bureaucratic demands and lost their radical political mission, artists still used this space to express the ideas, values and goals of this movement to a new generation. Additionally, with time, as the women's movement itself evolved, the messages in the music kept the issues alive but with a different focus. In the

\footnotetext{
${ }^{4}$ Eyerman and Jamison, Music and Social Movements, 164.

${ }^{5}$ Ibid., 170.

${ }^{6}$ Ibid., 17.

${ }^{7}$ Ibid., 164.

${ }^{8}$ Ibid., 78.

${ }^{9}$ Ibid., 23.

${ }^{10}$ Ibid., 43.
} 
music, the liberal and radical ideas of the early movement were replaced by the Third Wave's emphasis on cultural production, diversity, and personal narrative. ${ }^{11}$ As both these movements have been revived over the last few years, they have reflected this shift in perspective. Like the music, the political demands have changed. Indeed, in some ways, these new movements are less concerned with political change per se and more with cultural change as a political act in itself. That is, they seek to "reform broader dimensions of social life." 12

The focus on women singer-songwriters, rather than a specific genre of music, has been chosen for two reasons. First, exemplary action in the form of music is not limited to any particular genre. Music dealing with rape or domestic violence covers all genres, including blues, pop, country, folk/folk rock, rock, ska and hip hop. The selection here is limited because of space constraints, but covers several of the genres to show the diversity of the musical styles. ${ }^{13}$ Second, women singer-songwriters are chosen because of the need to link the music to action. The majority of the women selected have not only created and performed music dealing with rape and/or domestic violence, they also have been actively involved in feminist or other social justice movements, though some more than others. In addition, at least two of the women (Tori Amos and Lady Gaga) have spoken about their rape experiences, so it is possible to connect their music with their lived experiences. There will also be some discussion of other women singersongwriters, but the focus will be on Mitchell, Chapman, Amos, DiFranco and Lady Gaga.

\section{The Movements}

In order to explore the exemplary actions of Chapman, Amos, DiFranco and Lady Gaga, it is necessary to understand the context of the social movement in which these actions take place, the feminist movement. One aspect of this movement that bears consideration is the division of the movement into Waves. The use of the wave metaphor is contested, with some scholars arguing that it should be abandoned, renegotiated or regenerated, ${ }^{14}$ but this brief summary will use the wave metaphor, as it will play a role in the later analysis.

The First Wave refers to the suffrage movement of the nineteenth and early twentieth centuries. The Second Wave includes the "Women's Liberation Movement" of the 1960s and 1970s and the Third Wave refers to the current movement. The anti-rape and anti- domestic violence movements grew out of the Second Wave (1960s-1970s) of the Women's Rights Movement. This movement was composed of many feminists who differed ideologically. Most prominent in the United States were the liberal feminists who

\footnotetext{
${ }^{11}$ R. Clair Snyder, "What is Third Wave Feminism? A New Directions Essay," Signs 34, no. 1 (2008): 175-96.

${ }^{12}$ Eyerman and Jamison, Music and Social Movements, 17.

${ }^{13}$ Scholars have already examined these issues, though with a different focus, for country and hip-hop music. See Cheryl L. Keyes, "Empowering Self, Making Choices, Creating Spaces: Black Female Identity via Rap Music Performance," The Fournal of American Folklore 113, no. 449 (Summer 2000): 255-69; Sheila Simon, "Greatest Hits: Domestic Violence in American Country Music," Oregon Law Review 82 (2003): 1107-23; Shanara R. Reid-Brinkley, "The Essence of Res(ex)pectability: Black Women's Negotiation of Black Femininity in Rap Music and Music Video, Meridians: Feminism, Race, Transnationalism 8, no. 1 (2008): 236-60; Ronald Weitzer and Charis E. Kubrin, "Misogyny in Rap Music: A Content Analysis of Prevalence and Meanings," Men and Masculinities 12, no. 1 (2009): 3-29; Travis L. Dixon, Yuanyuan Zhang, and Kate Conrad, "Self-Esteem, Misogyny and Afrocentricity: An Examination of the Relationship between Rap Music Consumption and African American Perceptions," Group Processes E Intergroup Relations 12, no. 3 (2009): 345-60; and Ruby M. Gourdine, and Brianna P. Lemmons, "Perceptions of Misogyny in Hip Hop and Rap: What Do the Youths Think?" Fournal of Human Behavior in the Social Environment 21, no. 1 (2011): 57-72.

${ }^{14}$ Amber E. Kinser, "Negotiating Spaces for/through Third Wave Feminism," NWSA fournal 16, no. 3 (2004): 124-53; Snyder, "Third Wave Feminism," 175-96; and Nancy A. Hewitt, "Feminist Frequencies: Regenerating the Wave Metaphor," Feminist Studies 38, no. 3 (2012): 658-80.
} 
were represented by organizations such as the National Organization for Women (NOW), the National Women's Political Caucus, (NWPC) the Women's Equity Action League (WEAL), and the National Abortion Rights Action League (NARAL). ${ }^{15}$ Liberal feminism is based on the traditional Lockean liberalism that is the foundation of American government and politics, and simply adds women and stirs. Liberal feminism emphasizes rights, but does not challenge the existing structures and institutions of society and government. The emphasis of liberal feminism is on securing "equal rights" and legal reforms of laws which discriminate against women such as employment and compensation statutes or those that fail to adequately protect women, such as rape and assault laws. ${ }^{16}$

In addition to liberal feminists, there were also radical feminists who were very active during the 1960s and 1970s. Radical feminism takes women's oppression as the fundamental oppression (occurring before and deeper than all other oppressions) and demands a revolutionary restructuring of the political, social, and economic institutions of society. ${ }^{17}$ Yet, the real significance of the radical feminists came not from their theory, but from their method. Radical feminist groups came to their theories through the use of consciousness raising (C-R). In consciousness raising, small groups of women came together and shared their experiences as women with each other. In these groups women began to realize that their individual experiences were shared by many women. ${ }^{18}$ As women saw that they had shared problems, they were able to see that their problems were not personal, but political as well. As MacKinnon notes, feminist theory "moves from practice to theory," it is based in the concrete reality of women's lives. ${ }^{19}$

There are many criticisms of the Second Wave, but the primary one is that the Second Wave was mostly white and middle-class and failed to address the issues of women of color and poor and workingclass women. The first non-patriarchal criticisms of the Second Wave came from black feminists such as Audre Lorde, Barbara Smith, bell hooks, and Kimberle Crenshaw. Over time, a new generation of feminists, the daughters of the Second Wave feminists, declared themselves to be the Third Wave. Much like the Second Wave feminists relied on consciousness-raising as the road to the political, the Third Wave places an emphasis on personal narratives to learn about the world, but rejects the notion of a common experience among women. The Third Wave also considers itself to be more inclusive and racially diverse than the second wave. Lastly, the Third Wave stresses cultural production and critique over traditional politics. ${ }^{20}$ While these are clearly oversimplifications of both Waves, they will provide place to analyze the exemplary action of the selected women singer-songwriters.

The Anti-Rape Movement. Accounts of the anti-rape movement usually trace its origins to the CR groups of the early 1970s. Consciousness raising groups provided a space where women could openly speak about their daily lives without fear of judgment from the group. As more and more women began to speak about their rapes, they began to understand the prevalence of the experience and to discuss the issue not as an individualized experience fraught with guilt and anxiety, but as an issue of male dominance. ${ }^{21}$ Some groups struggled to not evolve into group therapy sessions because the purpose of the C-R group

\footnotetext{
${ }^{15}$ Mary Lyndon Shanley, Women's Rights, Feminism, and Politics in the United States (Washington, D.C.: American Political Science Association, 1988); Rosemarie Tong, Feminist Thought: A More Comprehensive Introduction, 3rd ed. (Boulder, CO: Westview Press, 2009).

${ }^{16}$ Tong, Feminist Thought.

${ }^{17}$ Ibid., 49.

${ }^{18}$ Ibid., 48.

${ }^{19}$ Catherine MacKinnon, Women's Lives, Men's Law (Cambridge, MA: Harvard University Press, 2005$), 23$.

${ }^{20}$ See Snyder, "Third Wave Feminism," 175-96.

${ }^{21}$ Maria Bevacqua, Rape on the Public Agenda: Feminism and the Politics of Sexual Assault (Boston: Northeastern University Press, 2000), 50.
} 
was to take the personal to the political and then to move toward political action as a group. ${ }^{22}$ In most cases, these groups did take political action through self-defense collectives, speak outs, conferences and, most importantly, the creation of rape crisis centers. ${ }^{23}$

The liberal feminist groups such as the National Organization for Women (NOW), the Women's Equity Action League (WEAL) and the National Women's Political Caucus (NWPC) were much slower to pick up the issue. NOW's first public recognition of the issue came in 1973 with the passage of Resolution 148, which created the NOW Rape Task Force. ${ }^{24}$ Consistent with the liberal feminist emphasis on rights and legal reform, the efforts of NOW on the issue were directed toward the reform of rape law. Although the 1980s and 1990s saw significant success in reform some of the most egregious problems with rape law-corroboration and resistance requirements, emphasis on penile penetration of the vagina as defining characteristic of rape, and the use of a victim's sexual history-rape reform has been limited in terms of changing the attitudes of lawyers, prosecutors, judges, and juries. All states have eliminated the marital rape exemption, but these laws still make it difficult for a woman to prove non-consent. While these reforms are important politically and legally, rape crisis centers were the center of both individual and cultural transformation.

The original rape crisis centers focused not simply on providing recovery services to victims, but also on outreach and education for victims and their communities. That education included an emphasis on the radical feminist project of contextualizing and politicizing the rape experience and ultimately on changing the society and institutions and gender relations that allow rape to occur. ${ }^{25}$ Yet, the major problem faced by rape crisis centers was the lack of funding. ${ }^{26}$ In order to survive, many rape crisis centers eventually began accepting state and federal funding and the inevitable restrictions on their activities that came with that money. As rape crisis centers began affiliating with law enforcement and hospitals, they soon discovered that their transformative efforts were not acceptable to the officials who provided their funding. Most rape crisis centers emphasized collective governance, but state and federal monies stipulated an organizational hierarchy and professionally trained staff. As these structures were put into place, radical feminists were pushed out and the rape crisis centers lost their focus on the politicization of rape and ended up simply as places for individual women to recover from their trauma. ${ }^{27}$

The project of politicizing rape included not only identifying the prevalence of rape, but also on reconceptualizing rape by exposing the many rape myths that shaped public consciousness regarding rape. ${ }^{28}$ The primary argument put forth was that rape was a crime of violence, not sex. This argument was widely accepted in the early years of the movement and is even reflected in much rape reform law that began referring to rape as sexual assault or sexual battery. Though this distinction has been challenged by some feminists ${ }^{29}$ it was considered primary to the radical feminists because many of the other myths were based on the idea that rape was simply about sex, or as MacKinnon would say, was nothing more than sex. These myths included the idea that rape is linked to women's appearance and dress, that women invite or desire rape, that women say no when they mean yes, that rape is not possible if a woman resists, that women who

${ }^{22}$ Bevacqua, Rape on the Public Agenda, 51.

${ }^{23}$ Ibid., 50-51.

${ }^{24}$ Ibid., 35.

${ }^{25}$ Ibid., 74.

${ }^{26}$ Schechter, Women and Male Violence: The Vision and Struggles of the Battered Women's Movement (Boston: South End Press, 1982), 41-43; Bevacqua, Rape on the Public Agenda, 74.

${ }^{27}$ Schechter Women and Male Violence, 42-43.

${ }^{28}$ Bevacqua, Rape on the Public Agenda, 59.

${ }^{29}$ See MacKinnon, Women's Lives. 
have consented to sex once always consent to sex (only a chaste woman can be raped), and that women make false allegations out of revenge or spite. Other myths addressed were the idea that most rapes were interracial and happened mostly to poor, minority women. The latter, it turns out, is not actually a myth. Poor and minority women do indeed experience higher rates of rape, but usually by men of their own race or ethnicity. ${ }^{30}$

One way that radical feminists helped bust some of these myths was by allowing women to tell their stories. Thus, it became clear that rape was not usually committed by a stranger, that many rapists use the threat of force rather than actual force to get women to submit, that any woman of any age, race, or class is a potential victim (though, again, young, poor, and minority women still experience greater rape rates), and that women are much more likely to fail to report a rape than to falsely accuse.

The Domestic Violence Movement. The first domestic violence shelters were created in the mid-1960s by Al-Anon groups in California (Haven House in Pasadena) and Arizona (Rainbow Retreat in Phoenix). ${ }^{31}$ These shelters were for women being abused by alcoholic husbands, and like all shelters to come, they struggled to find the resources needed to deal with the number of women who sought their support and resources. ${ }^{32}$ By the early 1970s, more and more shelters began to open. These often developed out of local women's centers, though some were started by individual women who had also suffered abuse and understood the problems facing abused women. ${ }^{33}$ In addition to protection from their abusers, many women needed legal advice and advocacy as they negotiated the legal system, help navigating the bureaucratic maze surrounding public assistance, counseling, and education, job training, and job opportunities. ${ }^{34}$

At the time of the creation of the first domestic violence shelters, the social and legal climate did not favor justice for abused women. Domestic violence, though clearly common, was considered both socially and legally to be a private matter that should be resolved by individual or couples counseling. Despite the evidence that domestic violence was the reason for most violence-related injuries of women, the medical community labeled battered women who stayed with their abusers as masochistic and thus it was a personal failing. ${ }^{35}$ The police also treated domestic violence as a personal or social problem and few cases entered the criminal justice system. Indeed, in some states, these cases were transferred to the civil courts where penalties for the abusers were light. Instead, police became counselors and mediators. ${ }^{36}$ The underlying legal assumption, derived from the common law tradition, was that a man could moderately chastise his wife and children and it was only a problem if the violence resulted in serious injury.

Like the anti-rape movement, the women of the domestic violence movement came from diverse ideological backgrounds. The first shelters were not explicitly feminist, but as time went on, feminism came to be very relevant to the movement and influenced the thinking of many who ran the shelters. Many who first joined the movement came from a social work or legal background and often leaned

\footnotetext{
${ }^{30}$ RAINN, “Scope of the Problem.” Statistics | RAINN. Accessed April 1, 2015. https://www.rainn.org/getinformation/statistics/frequency-of-sexual-assault.

${ }^{31}$ SafeNetwork: California's Domestic Violence Resource, Herstory of Domestic Violence: A Timeline of the Battered Women's Movement, published by Minnesota Center Against Violence and Abuse, 1999, accessed October 10, 2011, http://www.mincava.umn.edu/documents/herstory/herstory.html.

${ }^{32}$ Schechter, Women and Male Violence, 55-56.

${ }^{33}$ Ibid., 56.

${ }^{34}$ Ibid., 87.

${ }^{35}$ SafeNetwork, Herstory of Domestic Violence.

${ }^{36}$ Ibid.
} 
toward liberal feminism's emphasis on rights. ${ }^{37}$ These women felt that equality was the answer and institutionally all that was needed was reform of the system. These women pushed for legal reforms such as restraining orders (with real consequences for their violation), warrantless and/or mandatory arrest and prosecution through the criminal justice system. ${ }^{38}$ In the 1970 s, anti-domestic violence groups brought lawsuits against police departments for negligence and violation of the equal protection clause for failing to protect women in domestic violence situations. ${ }^{39}$ As a result many states passed mandatory or preferred arrest laws that either mandated an arrest in these cases or indicated to police that arrest was the preferred response. These resulted in modest increases in arrest, prosecution, and conviction in the 1970s and 80s (7\%-14\%) and even greater increases by the 1990 s-2000s (nearly $30 \%) .{ }^{40}$

Many feminist academics and clinicians focused on the causes of violence and the reasons why women stayed with abusers and, for them, the culprit was patriarchy and/or capitalism. Domestic violence, like rape, is a tool of the patriarchy used to control women, a way to keep women in their place-in the home and subservient - in defense of male dominance. ${ }^{41}$ These women stressed educating women for political/feminist consciousness and providing them with self-help strategies. The medical community also soon came to rethink battering. There is today a plethora of theories on why men batter, including theories based on the historical legacy of male ownership of women, battering as a form of control, women's inferior status in the capitalist system, and gender roles in the family. ${ }^{42}$ The movement also resulted in research on battered women themselves and eventually recognition by both the medical and legal professions of battered women's syndrome. ${ }^{43}$

\section{Women Singer-Songwriters as Exemplary Actors}

According to Eyerman and Jamison, it is through individual movement intellectuals and movement artists that culture and politics are combined to produce social change. They note:

It is within movement space that artists, singers, and songwriters uncover a new dimension to their work as they discover a new identity for themselves and for their art. In and through their role as artist-activist or activist performer such individuals help constitute the cognitive praxis of social movements and at one and the same time revitalize and revise tradition, creating the possibility of transforming the wider, dominant culture. ${ }^{44}$

This contrasts with the artist who lives a more bohemian lifestyle where art is life, an end in itself. These bohemian artists reject any involvement in politics as "an intrusion and distortion of aesthetic practice." For these artists, the dominant culture imposes too many limitations on their artistic expression. For those linked to social movements, however, the movement provides opportunities for them to experiment and innovate aesthetically and to be a political as well as a cultural agent who can help shape a merging cultural

\footnotetext{
${ }^{37}$ Schechter, Women and Male Violence, 45.

${ }^{38}$ Mary P. Koss et al., No Safe Haven: Male Violence Against Women at Home, at Work, and in the Community (Washington, D.C.: American Psychological Association, 1994), 101-2.

${ }^{39}$ David Hirschel et al., "Domestic Violence and Mandatory Arrest Laws: To What Extent Do They Influence Police Arrest

Decisions?" The fournal of Criminal Law and Criminology (1973-) 98, no.1 (2007): 257.

${ }^{40}$ Ibid., 258.

${ }^{41}$ Schechter, Women and Male Violence, 46.

${ }^{42}$ Ibid., 209-31.

${ }^{43}$ Schechter, Women and Male Violence, 232.

${ }^{44}$ Eyerman and Jamison, Music and Social Movements, 164.

${ }^{45}$ Ibid., 165.
} 


\section{formation. ${ }^{46}$}

Yet, there is one problem with Eyerman and Jamison's notion that an artist must be a part of a movement to engage in exemplary action intended to transform the larger culture. As will be shown below, there are artists who are not actively involved in any particular social movement (indeed, who even reject the idea of political labels and active involvement) who still write and perform music that is exemplary in terms of some social movements. Others only write one or two songs that can be described as exemplary in terms of one particular issue, such as domestic violence, yet who write many other exemplary songs around other social justice issues. Thus, when selecting women singer-songwriters to be examined in this research, the choices are not limited to only those actively involved in the anti-rape, antidomestic violence, or feminist movements.

With the large number of songs about rape and domestic violence across many genres, there are many women singer-songwriters who would count as exemplary actors, but space requires limiting the number of women to be examined. The women chosen (Joni Mitchell, Tracy Chapman, Tori Amos, Ani DiFranco, and Lady Gaga) were selected because they have written significant songs about rape or domestic violence, some have been actively involved in social justice movements generally or anti-rape and anti-domestic violence movements specifically, they represent different genres, they represent different generations, and they have had significant commercial success or, at least, long, productive careers.

\section{The 1990s and Early 2000s}

Although the 1990s did not see a total disbanding of the anti-rape and anti-domestic violence movements, most of the effort went on outside the view of the media and the general public. Shelters and rape crisis centers were available to many women and laws had been reformed, but reporting, prosecution and conviction rates had increased only minimally and were still low. The political movements shifted their focus from state level legal reforms to the national level. In 1994 women's groups successfully pushed for passage of the Violence Against Women Act (VAWA). The VAWA was designed to produce results that could not be achieved at the state and local level alone. According to the White House, the law attacked the problems of rape and domestic violence by strengthening federal penalties for repeat sex offenders, creating a federal rape shield law which prevents offenders from using victim's past sexual conduct as a defense, mandating that victims not bear the costs of their own rape exams or for service of a protective order, assisting communities to develop dedicated law enforcement and prosecution units, and training law enforcement, prosecutors, victim's advocates, and judges how to respond in crisis situations. ${ }^{47}$ The most controversial section of the law (which attempted to expand the jurisdiction of the federal government over rape cases) was held unconstitutional by the Supreme Court in United States v. Morrison, 529 U.S. 598 (2000), but the remainder of the law remained in effect. This is the context for the music of Joni Mitchell, Tracy Chapman, Tori Amos, and Ani DiFranco.

Joni Mitchell. For some of a certain age, Joni Mitchell is the ultimate queen of the singersongwriters. Her career has spanned over forty years, though her recent brain aneurysm likely means she will no longer be producing music. Mitchell, known for her unorthodox guitar tunings and poetic lyrics, has transitioned through folk, rock/pop and jazz with songs that explore life, love, relationships, society,

\footnotetext{
${ }^{46}$ Ibid., 165.

${ }^{47}$ WhiteHouse.gov, "Factsheet: The Violence Against Women Act," accessed March 30, 2015, https://www.whitehouse.gov/sites/default/files/docs/vawa factsheet.pdf.
} 
and politics. Her most recent album, Shine (2007), is one of the most politically laden, but from the beginning, Mitchell has addressed political issues in her music. Yet, unlike Amos, DiFranco, Chapman, and Lady Gaga who acknowledge their feminism and are active in social movements, Mitchell has eschewed the feminist label and activism. ${ }^{48}$ This, however, has not stopped her from writing songs with feminist sensibilities and some about rape and domestic violence.

In her early explorations of relationships, Mitchell often addressed the issues of gender roles and the restrictions they placed on both women and men. ${ }^{49}$ She was often very sympathetic to the situation of men (see "The Conversation" and "The Arrangement") and sometimes of women "Harry's House/Centerpiece" and "The Hissing of Summer Lawns"). Yet, by the 1990s, she began to write music dealing with women's issues from a much wider, political perspective. In 1994, with the release of her Turbulent Indigo album, she told the Detroit Free Press that she had been thinking about justice and “... in my search for justice, the injustices that seemed to be jumping out at me from most places were women's issues." ${ }^{50}$ It was then that Mitchell began to address the issues of rape and domestic violence in her music. In "Cherokee Louise" from Night Ride Home (1991), she tells the story of a friendship between two girls, one of whom, Cherokee Louise, has run away from home. The narrator is searching for her friend and knows where she is likely hiding. She talks about their friendship and the recent restrictions put on Cherokee Louise. Finally Mitchell tells us why Louise has run away: "She runs home to her foster dad / He opens up a zipper / And he yanks her to her knees." Three years later, on the 1994 Turbulent Indigo album, Mitchell begins to take on the patriarchy. On this album, she takes on domestic violence in "Not to Blame," the Catholic Church in "The Magdalene Laundries," and just about everything else in "Sex Kills."

"Not to Blame" is the story of domestic violence that begins with a beating by a celebrity of some kind. After telling how the story has hit the news, Mitchell sings "Your buddies all stood by / They bet their fortunes and their fame / That she was out of line and you were not to blame." After noting that the medical profession is learning to identify battered women "among all the women they see bleeding through their lives," she then condemns the victim blaming: "I bleed for your perversity/ These red words that make a stain / On your white-washed claim that / She was out of line / And you are not to blame." She ends with the tale of another woman driven to suicide by her abuser with still no recognition of the role played by the abuser, "Not one wet eye around / Her lonely little grave / Said 'He was out of line girl / You were not to blame'." Unlike almost all of the other songs addressed so far, Mitchell does not tell just one story. Instead she tells three and she gives the song a wider political context when she addresses three issues that arise-the patriarchal defense of batterers, the medical professions' growing awareness of battering, and the pain and suffering of the abused.

Magdalene Laundries were convent prisons where sexually threatening women (prostitutes, unwed mothers, and other wayward women) were held by the Catholic Church (without trial or due process) and forced to work for the remainder of their lives in laundries "to wash away their sins." 51 Very little was actually known about these laundries by the general public until 1999 when their existence in Ireland was exposed and became a national scandal. They were not limited to Ireland, however. They existed throughout the world, including in the United States. Mitchell's song, which predates the Irish scandal, is

\footnotetext{
${ }^{48}$ Lloyd Whitesell, The Music of Foni Mitchell (Oxford: Oxford University Press, 2008), 241, footnote 2, for chapter 4. ${ }^{49}$ See Whitesell, The Music of Foni Mitchell, chapter 4.

${ }^{50}$ Gary Graff, "Joni Mitchell Looks at the Darker Side,” Detroit Free Press, October 23, 1994, archived on jonimitchell.com. Accessed November 14, 2011, http://jonimitchell.com/library/view.cfm?id=971.

${ }^{51}$ Violet Feng, "The Magdalene Laundries," CBS News, August 8, 2003, accessed November 14, 2011, http://www.cbsnews.com/stories/2003/08/08/sunday/main567365.shtml.
} 
not specifically about rape or domestic violence, but in telling the story of the Magdalene Laundries, Mitchell notes that many, if not most, of the women sent to the laundries were pregnant_- "Some by their own fathers / Bridget got that belly / By her parish priest." This is a story told in the first person, but one that tells a gruesome and frighteningly long history of an institution used to control women, limit their sexuality, and punish them for being raped and abused.

The issue of sexual assault, alongside sexual harassment, is raised again on Turbulent Indigo in the song "Sex Kills." This song takes on the rich and powerful, greed, environmental degradation, debt, lawyers, road rage, child abuse, school shootings, and the use of sex to sell everything. Among the list of complaints, Mitchell includes sexual harassment and rape when she sings "All these jackoffs in the office / The rapist in the pool." "No Apologies" is another song taking on the problems of the modern world, which Mitchell sees arising from modern masculinity and the patriarchal system. It begins with the story of three Marines who raped a twelve-year old Japanese girl on Okinawa Island. Following the rape, Admiral Richard C. Macke caused an uproar when he said at a press conference, "I think it was absolutely stupid. I have said several times: for the price they paid to rent the car, they could have had a girl." ${ }^{, 52}$ Mitchell writes, "The general offered no apologies / He said, 'The soldiers erred in judgement / They should have hired a hooker." The chorus, sung three times throughout the song, asks: "Tire skids and teeth marks / What happened to this place? / Lawyers and loan sharks / Are laying America to waste." This is a song about the rule of the patriarchs. In one verse, after referring to a man as the devil, Mitchell scoffs "What a lofty title / For such a petty little tyrant / Bigger beasts abound / And they kick this world around / At this crazy speed / Of violence and greed." She then asks, "So what makes a man a man / In these tough times / As drug lords buy up the banks / and warlords radiate the ocean." Thus, Mitchell once again puts a story of rape into the larger political context, all the while using it to symbolize what she sees as the problem-the patriarchy.

Even though Mitchell long avoided the feminist label and has never been actively involved in any political or social movements, there is no doubt that her music provides examples of exemplary action. She grew to see the issues facing women as reflections of the larger injustices of a society focused on the patriarchal values of greed, environmental degradation and war and used her music to speak the truth, educate, and raise consciousness among her listeners. Since Mitchell's audience would mostly be from the generation who experienced or was familiar with the Civil Rights, Anti-War and Women's Movements, they may have not needed education or consciousness-raising, but others, like Mitchell herself, may have grown and changed their perspectives and lives along with her.

Tracy Chapman. Tracy Chapman is an African American folk/blues singer-songwriter. Since 1988 Chapman has released 8 studio albums, several of which have gone platinum. ${ }^{53}$ She has also received four Grammy Awards. According to her website, Chapman was born to a poor single mother in Cleveland, Ohio. Through a program that assisted minority students to attend private schools, Chapman was able to attend Wooster School in Connecticut and eventually graduated from Tufts University. Throughout her career, she has supported programs directed at economically disadvantaged youth, including providing scholarships for many. ${ }^{54}$

\footnotetext{
${ }^{52}$ Irvin Molotsky, “Admiral Has to Quit Over His Comments on Okinawa Rape” New York Times online edition, November 18, 1995, accessed November 14, 2011, http://www.nytimes.com/1995/11/18/world/admiral-has-to-quit-over-his-commentson-okinawa-rape.html.

${ }^{53} \mathrm{http}: / /$ www.tracychapman.com/.

${ }^{54}$ http://www.about-tracy-chapman.net/.
} 
It was at Tufts that Chapman was discovered by the son of Charles Koppelman of SBK Publishing. Koppelman helped her sign with Elektra Records. ${ }^{55}$ Like Mitchell, Chapman's music is both personal and politically laden, with an emphasis on human rights and the poor. She is a very private person and avoids the spotlight and the press, but has been very active in concerts benefiting a variety of social movements, including AIDS, Amnesty International, Tibetan independence, We the Planet (environmental issues), as well as Lilith Fair. On her first album, the self-titled Tracy Chapman (1988), she addressed several human rights issues, including violence against women. Her song "Behind the Wall" is a quintessential example of exemplary action.

In "Behind the Wall," Chapman sings a cappella about hearing a woman being abused next door. The fact that this song is sung a cappella gives the story more power. The lack of instrumentation emphasizes the seriousness of the narrative. The song addresses the sense of hopelessness felt by bystanders observing (or hearing) a woman being beaten and the failure of the police to respond and deal with the violence. She sings "Loud voices behind the wall / Another sleepless night for me / It won't do no good to call / The police / Always come late / If they come at all." In the next verse she notes the failure of the police to intervene "With domestic affairs / Between a man and his wife." Ultimately the song ends with the woman being either seriously injured or killed, "Last night I heard the screaming / Then a silence that chilled my soul." Again, here the lack of instrumentation adds to the tension. This time the police come, only to disperse the crowd that has gathered at the arrival of the ambulance. Ironically, the police officer announces, "I am here to keep the peace / Will the crowd disperse? / I think we could all use some sleep."

This song deals with the problem first confronted by the battered women's movement - the notion that a man could chastise his wife and that violence in the home was not to be dealt with legally, but as a civil or mental health issue, or not at all. The police are called multiple times, yet fail to make an arrest. Sometimes they do not even show up. One of the main efforts of the battered women's movement was to change the laws and force the police to deal with domestic violence and to make arrests. Yet, this song, released in 1988, recognizes that despite a decade of education and legal reform, women cannot depend upon the police to protect them-only to clean up the mess after it is too late.

By the time Chapman released "Behind the Wall," the anti-domestic violence movement had achieved some success. Domestic violence shelters were numerous and the public and public sphere had been educated on the prevalence of the issue. The movement had also made significant efforts to change the approach of the law and law enforcement to the issue. By the 1980s the number of arrests, prosecutions and convictions for domestic violence has increased minimally, ${ }^{56}$ but there was still a long way to go and "Behind the Wall" brought that message to the fore.

Chapman has several other songs that deal with the use and abuse of women. In "Never Yours" from Where You Live (2005), she sings of a woman who despite being "given to a man" in payment for a debt, still maintains her agency: "It was a bet / A game of pool or cards / I repay my family's debt / I let you lie beside me / With no remorse / I've been a lot of things / But never yours." In "Across the Lines" from Tracy Chapman, she tells the story of a race riot that ensues following the assault of a young black girl and in "Why" from the same album she sings "Why is a woman still not safe / When she's in her home / Love is hate / War is peace / No is yes / And we're all free." Unlike "Behind the Wall," these songs place the

\footnotetext{
${ }^{55} \mathrm{http}: / /$ www.tracychapman.com/.

${ }^{56}$ Hirschel et al., "Domestic Violence and Mandatory Arrest Laws," 258.
} 
issues of rape and domestic violence within a larger political and social context and show her commitment to speak these truths.

Tori Amos. Another exemplary actor of this time period is Tori Amos, a classically trained pianist. Amos released her first album, Little Earthquakes, in 1992, and has since produced seventeen albums. She not only writes explicitly feminist music, she is also a founding member of RAINN (Rape Abuse and Incest National Network) which is the largest anti-sexual violence organization in the U.S. RAINN provides both a phone and online hotlines, educates about sexual violence and leads national efforts to prevent sexual violence, improve services to victims and ensure that rapists are brought to justice. ${ }^{57}$ Amos is a rape survivor. Of all these women, she is most exemplary in that she is not only spreading the message and vision of the movement, she is active in the movement as well.

Amos' "Me and a Gun" from Little Earthquakes is an upfront, unambiguous rape song which she, like Chapman in "Behind the Wall," sings a cappella. The song, written in the first person, begins with the aftermath of the rape during which Amos is driving around in the early morning, unwilling to go home for fear the rapists are following her and will learn where she lives. Amos then describes the material reality of the rape ("it was me and a gun and a man on my back") as well as the psychological strangeness of the situation ("it's kinda funny, the things you think at times like these"). Yet, what makes this song different is that Amos puts the political context into the material and psychological story when she asks, "Yes, I wore a slinky red thing, does that mean I should spread for you, your friends, your father, Mr. Ed?" Later, Amos questions the whole situation with a significant change in her voice, expressing anger rather than sadness at the entire situation.

The power of this song lies not only in Amos' singing, but also in the way it addresses some of the most difficult aspects of society's usual response to rape. She is afraid to drive home because while home may be a safe place, she fears the rapists will follow her. She questions whether she caused this to happen because of the way she was dressed (a rape myth). Later she recalls a conversation she had with Jesus (Amos' father was minister and religion is continually referenced and often challenged in her music) where he advises her to "choose well" since she will not return after three days if she dies, she asks him "is it my right to be on my stomach in the back of Fred's Seville?" For many rape survivors, self-blame often haunts them, a result of society's and the law's view that women ask to be raped. Yet, Amos rejects selfblame in her angry expression of and answers to these questions.

This song may be the first song written specifically about a particular rape experience from the perspective of a survivor. ${ }^{58}$ Amos' straightforward honesty in "Me and a Gun" paints a picture at once personal and material, but also psychological and political. She gives her listeners not just a narrative, but also a feminist political critique of the experience. In this way, it is clearly an example of exemplary action. "Pandora's Aquarium," on the other hand, is much more abstract and thus somewhat less plausible as a rape song. Yet, it is a song that inspired the creation of a web-based support group for the survivors of sexual violence known as Pandora's Project and which Amos has indicated in her book, Piece by Piece, is about healing from rape/incest. ${ }^{59}$ Here the long and difficult struggle of healing from sexual violence is described in an aquatic metaphor: "you're still alive below the waves / Ripples come and ripples go / And

\footnotetext{
${ }^{57}$ RAINN, “Mission Statement," accessed October 31, 2011, http://www.rainn.org/about-rainn/mission-statement.

${ }^{58}$ I do not claim to have identified every song ever written, recorded, and performed about rape or domestic violence. It is also unclear to this writer if "The Boiler" which preceded Amos' "Me and a Gun" was written about a particular experience of the performer.

${ }^{59}$ Tori Amos, Piece by Piece (New York: Broadway Books, 2005), 154-57.
} 
ripple back to me... I'm not asking you to believe in me / Boy I think you're confused / I'm not Persephone." The song itself is open to many interpretations, but it is clear that both Amos and some survivors understand the song. In Piece by Piece, Amos acknowledges that it is not a song that will be "ingested" by the masses, but will be for those who are engaged in a healing process. ${ }^{60}$

Amos also has at least two songs dealing with abusive relationships or domestic violence. "Silent All These Years," also from her debut album Little Earthquakes, is written in the first person and is about a woman whose partner yells at her ("I got the anti-Christ in the kitchen yellin' at me again") and cheats on her ("So you found a girl who thinks really deep thoughts") but who takes it all silently ("my scream got lost in a paper cup"). Yet, in the end, when her partner is embarrassed by his mother, the narrator offers him her hand. In this song, the woman is showing signs of consciousness of her abuse when Amos writes (and repeats as the chorus) "sometimes I hear my voice and it's been here / Silent all these years." This song is about a woman who, even if incapable of leaving the relationship, has begun to find her voice, to have her consciousness raised. This song actually follows two other songs on the album that deal with women's lives, "Crucify" which asks why women are so willing to suffer for love ("Why do we crucify ourselves / Every day I crucify myself / Nothing I do is good enough for you") and "Girl” which addresses a woman with no sense of herself ("She's been everybody else's girl / Maybe one day she'll be her own"). Taken together, these songs all challenge the listener to critically confront their relationships with their lovers or their families and find their voices.

In "Bells for Her" from Under the Pink, Amos writes from the perspective of an old friend watching her friend being abused by her lover. Actually, the song shifts back and forth between the first and third person, beginning with the third, sliding into the first and then back and forth throughout the song. Though not sung a cappella, the music is minimal, notes played on a "prepared" upright piano which indeed sound like bells. The story is of "blanket" friends from childhood who believe they will be able to get through anything. Yet, the chorus throughout the song is "can't stop what's coming can't stop what's on its way." Although the song never explains what is going on, Amos sings "Now she seems to be sand under his shoes there's nothing i can do / can't stop what is coming can't stop what is on its way... and now I speak to you are you there? you have her face and her eyes but you are not her... can't stop, can't stop loving ... can't stop what is on its way."

While Amos' abstract writing leaves plenty of room for interpretation, ${ }^{61}$ this song can easily be read as a song about a woman watching her friend become a battered woman. It can be read with (at least) two possible outcomes (what's coming). It could be that the two friends will simply no longer be friends, with one choosing her lover over her friend, or it could be the "bells for her" are church bells at a funeral, that what is coming is her friend's death at the hands of her abusive lover. Either interpretation works and both fit well into Amos' feminist sensibilities. Indeed, it is a story many women have experienced-helplessly watching their friend be isolated, then abused, all the while unable to convince the friend of the danger they are in. Isolation from family and friends is one of the first steps in the process of making a battered woman. Often the battering does not happen until the victim is isolated and seemingly without an escape route. This was one of the reasons for creating shelters and for educating women about the battering process.

Amos' feminist consciousness is evidenced throughout her music. She attacks the rape myth that

\footnotetext{
${ }^{60}$ Amos, Piece by Piece, 157.

${ }^{61}$ In Piece by Piece, Amos indicates that this song was inspired by her friend who is an incest survivor and who today struggles with bipolar disorder (156).
} 
women who dress sexily deserve to be raped and the self-blame many women encounter following a rape. She recognizes that healing is a long process that requires speaking the experience. She tells stories of women's masochism and silence and acceptance of it in intimate relationships. She explores women's relationships with each other and the frustration of those who must watch other women being abused. She gives these songs a political dimension by her constant questioning of these myths and realities and she speaks to women as women. But Amos is not the only women singer-songwriter to express her feminism in her music. She is joined in her efforts to reach women by Ani DiFranco.

Ani DiFranco. Ani DiFranco is a truly independent singer-songwriter. She kick-started her own career by selling tapes she recorded, touring alone, and then created her own record company, Righteous Babe Records. ${ }^{6}$ She has released more than 17 albums on her own label. She is a declared feminist and openly bisexual. DiFranco's music is guitar-driven and she is well known for her staccato style of playing. DiFranco has so many songs addressing rape, abuse and domestic violence that she deserves her own article, but three are particularly relevant: "Gratitude" from Not So Soft 1991; "Fixing Her Hair" from Imperfectly 1992; and "Two Little Girls" from Little Plastic Castle 1998. Three other songs will be briefly discussed: "Out of Range" and "Letter to John" from Out of Range 1994 and "Hide and Seek" from Living in Clip 1997. Musically, these songs are typical folk rock songs, driven by DiFranco's staccato guitar work and occasionally with limited percussion.

DiFranco's "Gratitude" from her 1991 album Not So Soft is about acquaintance rape. It is written in the first person and directly speaks to a man who has helped a woman in need of a place to stay. The man had said they could share his bed like "brother and sister," but then "changed the rules." The song begins with a list of thank yous-letting her stay there, beer and food, bus fare, showing her around, the use of a towel, and half of his bed-but when the man changes the rules, the woman asks him "I don't know what you and your sisters do / but please don't, please stop, this is not my obligation / what does my body have to do with my gratitude?" She then confronts the man for his lying, his justification of his actions, and ignoring her resistance. In the end, she thanks him again for his kindness, but tells him he cannot just treat her like an object to be used, that she is not turned on by him and again asks what her body has to do with her gratitude. The song is unresolved and one wonders if she was able to get him to see reason, whether she had to abandon his home because it is no safer than the streets, or whether she submitted from fear. That question is left for the listener to answer.

This song confronts men's sense of entitlement, their "right" of access to women's bodies, even in the face of clear resistance. DiFranco tackles this question head on and challenges her assailant. DiFranco's narrator is able and willing to try to defend herself and her right to bodily integrity. She has a voice and it is feminist in its demand for her rights and its rejection of the idea that he can continue his efforts despite her "No." Yet, what makes this song exemplary is the fact that DiFranco is sending a clear anti-rape message to men that they are not entitled to women's bodies and to women that they have the right to say no. The song strongly expresses the movement's value on women's bodily integrity and personal autonomy and presents a vision of a world where those are represented and respected.

In "Fixing Her Hair" DiFranco's narrator is with a friend who is preparing to go out with her boyfriend, who the singer does not like ("she's so happy / and i think this is not cool / 'cause i know the guy / she's been talking about). She addresses the way the man controls her and how her friend rationalizes

${ }^{62}$ Jason Ankeny, "Ani DiFranco: Biography," MSN Entertainment, accessed November 5, 2011, http://music.msn.com/music/artist/biography/anidifranco/?silentchk=1\&wa=wsignin. 10 . 
staying with this man when she sings "she tells me he don't mean what he do / she tells me he called to apologize / and he says he loves her / he says he's changing / and he can keep her warm." These rationalizations are common among battered women and highlight what we now know about the cycle of abuse-the control exerted, the early abuse, the batterer's contrition, followed by a period of peace only to be followed by more (and usually even worse) abuse. In this song, DiFranco expresses feminist sentiments in the lines "she is still playing the martyr / i am still praying for revolution." The song ends with the singer telling her friend that there are "really great men out there," but her friend does not hear her for she is "fixing her hair." This sense of helplessness is repeated in "Two Little Girls."

In "Two Little Girls," the narrator is talking to an old friend who is now a drug addict ("you know I would prefer she didn't empty her syringes into your arm") and beaten ("so now you show me your bruises so I can 'ooh' and 'aah' at the display"). DiFranco's narrator has found her friend "slumped on the bathroom floor" and does not know what to do. She says, "so I'll guess I'll just stand here with my back against the wall / while you distill your whole life down to a 911 call." In the last verses, the narrator asks what she is supposed to do: make a joke? be the handsome prince? be an understanding friend? Her response is again a sense of helplessness: "so I guess I'll stand here with my back against the wall..." Unlike Amos' "Bells for Her," DiFranco's “Two Little Girls" is not abstract and capable of multiple interpretations. This song is a straightforward lament for a friend who has become a drug addict and is apparently being physically abused by her lover (another woman). The friend is there for her, but just not sure how to respond.

DiFranco has several other songs dealing with violence against women. In "Out of Range," she writes in the first person as a woman thinking about a time when her lover "punched the wall beside my head." This song, however, is multi-layered and explores a larger political story. While it begins and ends with her exploring a personal relationship that she has chosen to escape, it also addresses gender roles and war. She sings of gender, "and boys get locked up in some prison, girls get locked up in some house / and it doesn't matter if it's a warden, a lover, or spouse" She sings of war, "all the men of the hour can kill half the world in war / make them slaves to the super power and let them die poor." In the chorus she sings, "you just gotta drive / out of range." This connection between the imprisonment of abusive relationships, gender roles, and imperialistic powers is a powerful example of making the link between the personal and the political. She is describing the long reach of the patriarchy. She shows how what happens at the personal level mirrors what happens at the social and political level. Yet, this song is pessimistic as she faces the fact that no one is willing to deal with the problems. Her response is then to simply "drive out of range."

In "Hide and Seek" DiFranco sings as a woman who has experienced sexual exploitation all her life, from her young male friends, from perverts in cars, from men on buses as she travelled across country. In the song, she acknowledges that while these experiences made her feel dirty and ashamed, she did not let it stop her "game." Yet, she ends with her admission that "... i could go on, but you know, it just gets worse" and a final note to the listener, "girl, next time he wants to know where the anger comes from / just tell him this time the problem is his." This song gets to the prevalence of sexual assault in women's lives and how many women simply accept it as normal, even though it fills them with anger. It also seeks to place blame for women's anger where it belongs, on the men who benefit from and help maintain patriarchal oppression of women.

In "Letter to John," DiFranco sings as a young prostitute telling her client that she doesn't want to be his friend, she just wants his money because "I want you to pay me for my beauty, I think it's only right / 
'cause I have been paying for it all my life." She acknowledges a rape when she was eleven and rejects the client's claim that what she does is indecent or that she should have some pride. Again, this is a story that addresses a little known truth, that most women who become prostitutes have been physically abused and raped as children. ${ }^{63}$ In addition, this song implies an alienation by the narrator from her beauty and body. It has become nothing more than a source of money. In both these songs, DiFranco provides voices to the women who do not seem to have the support and resources to heal from their trauma.

One interesting aspect of the music of these exemplary women is that the music contains elements of both the Second and Third Waves. They all include the major focuses of the Second Wave movements in their songs - rape myths, the cycle of abuse, the legal problems around domestic violence, the role of the criminal justice system, the expanding definition of rape, and the need to address the emotional needs of victims. As one would expect from singer-songwriters, the message is most often contained in personal narratives, a Third Wave preference to formal theory. R. Clair Snyder has noted that one problem with personal narratives is that the critical messages of the narratives often remain unspoken, leaving the readers to construct a critique of the dominant ideologies. ${ }^{64}$ These women, however, have succeeded in making the critical messages manifest in their narratives.

\section{The Early 2000s to the present}

There is strong evidence that rape rates have been falling in the United States. According to the FBI's Uniform Crime Reports, there were an estimated 83,425 forcible rapes reported to law enforcement in $2011 .{ }^{65}$ This indicates a $2.5 \%$ drop from 2010 and a $9.5 \%$ drop since $2002 .{ }^{66}$ Citing the National Crime Victimization Survey 1993-2013, RAINN actually notes in their statistical section that rape rates have decreased by $50 \%$ in recent years. ${ }^{67}$ It is difficult to find data on whether domestic violence rates have increased or decreased in the United States. Unfortunately, there are many difficulties with statistics in terms of both rape and domestic violence; all of the data consists of estimates (whether from law enforcement or victimization surveys), there are definitional issues that arise, and it is hard to know how the numbers are affected by increased reporting. Yet, the evidence does suggest that the anti-rape and domestic violence movements have had an effect on the numbers. The policy and legal reform efforts of both groups have resulted in change. In addition to putting these issues on the political agenda, they have been able to push the government itself to redefine rape. ${ }^{68}$ On the other hand, the most recent battle to reenact the Violence Against Women Act, which provides funding for crisis centers and shelters, was long and difficult. ${ }^{69}$ This is the context for the music of Lady Gaga and others.

Lady Gaga. Born Stefani Joanne Angelina Germanotta in 1986 and raised on the Upper West Side

\footnotetext{
${ }^{63}$ Melissa Farley and Howard Barkan, "Prostitution, Violence Against Women, and Posttraumatic Stress Disorder," Women E Health 27, no. 3 (1998): 37.

${ }^{64}$ Snyder, "Third Wave Feminism," 185.

65 "Forcible Rape," FBI, August 17, 2012, http://www.fbi.gov/about-us/cjis/ucr/crime-in-the-u.s/2011/crime-in-the-u.s.2011/violent-crime/forcible-rape.

${ }^{66}$ Ibid.

${ }^{67}$ RAINN, “Scope of the Problem.” Statistics | RAINN. Accessed April 1, 2015. https://www.rainn.org/getinformation/statistics/frequency-of-sexual-assault.

${ }^{68}$ Charlie Savage, "US to Expand its Definition of Rape in Statistics," New York Times online edition, January 6, 2012, http://www.nytimes.com/2012/01/07/us/politics/federal-crime-statistics-to-expand-rape-definition.html.

${ }^{69}$ Ashley Parker, "House Renews Violence Against Women Measure," New York Times online edition, February 28, 2013, accessed March 13, 2013, http://www.nytimes.com/2013/03/01/us/politics/congress-passes-reauthorization-of-violenceagainst-women-act.html.
} 
of Manhattan, Lady Gaga is one the most interesting women pop artists of this century. ${ }^{70}$ She learned classical piano, trained with Christina Aguilera's vocal coach, attended NYU's Tisch School of the Arts and began her career as a singer-songwriter-pianist in the New York cabaret clubs. She later turned to pop music. The name Lady Gaga was chosen when her producer sang Queen's "Radio Ga Ga" in response to some of her glam rock influenced beats. ${ }^{71}$ Between 2008 and 2014, she released 5 solo albums and another with Tony Bennett. She is well known for her interesting fashion choices. From the beginning, she has very much been in control of both her music and her image. According to Hiatt, ${ }^{72}$ she has bucked the control producers have over many musicians. Hiatt quotes producer Fernando Garibay: "We weren't used to having an artist be so in control. It's not in our repertoire, in this generation of producers, to have an artist that comes in and knows exactly what she wants." It is this personal control that positions Lady Gaga as a singer-songwriter.

Lady Gaga's music is considered pop/dance music and her flamboyant, often campy performances have made her popular with the gay community. She has identified as bisexual and in 2014, she and Elton John were nominated for a GLAAD Media Award. ${ }^{73}$ Lady Gaga has said that she was bullied while in school and she and her mother started a foundation called Born This Way (the title of her second album) to fight bullying and provide resources for young people who are encountering bullying, particularly LGBT students in schools. ${ }^{74}$ Lady Gaga's foundation and activity around it indicate that she is active in social movement.

Because Lady Gaga's career has not spanned as long a time period as the other women, she does not have as much music as the others that deal with rape. Indeed, she has only two songs, "Swine" for her Artpop album and "Til It Happens to You" co-written with Diane Warren and recorded for the documentary "The Hunting Ground." In terms of its lyrics, "Swine” is somewhat confusing. Despite the dance beat, there is clearly anger present, but it is unclear who is speaking or to whom (someone else or themselves). Indeed, no one knew it was an anti-rape song until Lady Gaga explained it in an interview with Howard Stern. ${ }^{75}$ When reporting on the story, the Washington Post noted: "With that knowledge, it allows for the performance, and even the lyric video for the song, to be viewed from an entirely different perspective." 76 Indeed, that knowledge brings clearly brings to mind the rape scene from the movie "Deliverance." Even with this is the reference, the narrator can still be either the rapist or the victim/survivor. On the other hand, Lady Gaga's comments suggest the Swine is the rapist. Regardless of the correct interpretation, the song is not exemplary until it is given some context.

The same is true for "Til It Happens to You." Without the context of the documentary, and the fact that both Lady Gaga and her co-writer Diane Warren are rape survivors, the song itself could be about any trauma. Lady Gaga also made that context clear in her Oscar performance by having rape survivors join her on stage and in song. In context, both "Swine" and "Til It Happens to You" are both powerful and

\footnotetext{
70 "Lady Gaga Biography," Rolling Stone online, http://www.rollingstone.com/music/artists/lady-gaga/biography.

71 "Lady Gaga Biography," Rolling Stone.

${ }^{72}$ Brian Hiatt, "Deep Inside the Unreal World of Lady Gaga," Rolling Stone online, June 9, 2011, http://www.rollingstone.com/music/news/deep-inside-the-unreal-world-of-lady-gaga-20110609.

${ }_{73}$ Jason Newman, "Elton John, Lady Gaga Nominated for GLAAD Media Awards," Rolling Stone online, January 20, 2014, accessed June 27, 2016, http://www.rollingstone.com/music/news/elton-john-lady-gaga-nominated-for-glaad-media-awards20140130.

74 "Lady Gaga Biography," Rolling Stone.

${ }^{75}$ Soraya Nadia McDonald, "Lady Gaga reveals that she was raped by a record producer when she was 19," Washington Post online edition, December 3, 2014, accessed March 30, 2015, http://www.washingtonpost.com/news/morning$\mathrm{mix} / \mathrm{wp} / 2014 / 12 / 03 /$ lady-gaga-reveals-that-she-was-raped-by-a-record-producer-when-she-was-19/.

${ }^{76}$ McDonald, "Lady Gaga reveals."
} 
emotional examples of exemplary action. They express the anger and pain of rape survivors. The success of "Til It Happens to You" is evidenced by the viral response of social media and even some politicians to a letter describing the consequences of rape on a woman written by a young woman who was raped while unconscious and whose rapist received a six-month sentence. ${ }^{77}$ Lady Gaga uses the concept of bravery in her work with bullied youth and it seems that both survivors and their political supporters are now finding the courage to speak out about their experiences. Yet, there is something missing from both these songs: an alternative vision of society and culture. In some ways, these are just angry complaints.

Unfortunately, expressing anger is not always an exemplary action. Anger over the status of women is also evident in the music of P!NK, who uses her music to address domestic violence in her family ("Family Portrait") and her personal life ("18 Wheeler") on her second album Missundaztood (2001). In both these songs, P!NK expresses anger at growing up in a dysfunctional family. "Family Portrait" is clearly about her parents. In " 18 Wheeler" P!NK sings about taking abuse, but concludes that nothing will keep her down. In fact, she asks the women of her audience to react defensively to abuse with "your shield and sword." Rather than seeking transformation of the society that creates and perpetuates abuse, P!NK almost seems to be saying "bring it on, we can take it." P!NK dresses up her anger in pop and dance music, even expressing her anger at her mother and other women in songs like "My Vietnam" from Missundaztood, "Stupid Girls" from 2006's I'm Not Dead and "Slut Like You" from The Truth About Love (2012). Yet, as Snyder argues regarding many of the Third Wave feminists, P!NK does not have a feminist framework within which to contextualize her anger. It is personal narrative, but it is not given real context in the lyrics or by connection to a social movement. While P!NK does represent Third Wave feminism in that in many of her songs she seeks to empower women, she is not as successful as an exemplary actor as Lady Gaga who has linked herself to the movements.

One brief mention about songs about domestic violence during this time period is necessary. Christine Aguilera and Jessica Simpson recorded songs about domestic violence committed against their mothers by their fathers: Aguilera's "I'm OK" and "Oh, Mother" from 2002's Stripped and Simpson's "Remember That" from 2008's Do You Know. All three of these songs are narratives that praise their mothers for surviving the violence and protecting them from it. These songs contrast with P!NK's "My Vietnam" which chastises and blames her mother. Aguilera's and Simpson's songs celebrate survival and encourage empowerment, but again do not really provide a strong critique of the issue.

In Snyder's critique of Third Wave feminism, she notes that Third Wave feminists "feel entitled to interact with men as equals" and, in their rejection of the category "woman" and their call for diversity and inclusion, they seemed to have abandoned the idea of feminism as a social movement. ${ }^{78}$ Yet, some Third Wave feminists, including Lady Gaga, have discovered that real change may only come about because of political and social movements. I suggest that the anger expressed in the music of the younger women singer-songwriters is due to their failure to get that to which they feel entitled and this has helped spur a revival of the anti-rape and anti-domestic violence movements. This revival is very Third Wave in that it relies on media, mainstream and social, and a web-based community.

The issues of domestic violence and rape have become major topics of media coverage. The video of Ray Rice knocking out his girlfriend, now wife, in a hotel elevator exploded onto the airwaves and social

\footnotetext{
${ }^{77}$ John Schuppe, "Vice President Joe Biden to Stanford Rape Victim: You are a Warrior," NBC News online, June 9, 2016, accessed June 27, 2016, http://www.nbcnews.com/news/us-news/you-are-warrior-biden-pens-open-letter-stanford-rapevictim-n589151.

${ }^{78}$ Snyder, "Third Wave Feminism," 179-86.
} 
media brought the issue of domestic violence, especially by athletes and celebrities, once again to the public consciousness. ${ }^{79}$ The issue of sexual assault on college campuses has also received widespread coverage as students have begun organizing and protesting against the failure of universities to appropriately handle incidents of sexual assaults as well as their failure to deal with the "rape culture" of college campuses. ${ }^{80}$ There has also been an active shift toward social transformation. Several educational programs have been created to deal with rape and violence on college campuses including the Red Flag Campaign, ${ }^{81}$ It's On Us, ${ }^{82}$ and Green Dot. ${ }^{83}$ These peer-based programs are designed to discourage and prevent sexual assault on college campuses. These prevention efforts have shifted the discussion away from one that is primarily victim centered to one that also includes an emphasis on the perpetrators through intervention by bystanders. The students themselves are encouraged to become active in preventing violence (sexual and physical) in an effort to change the culture that supports the violence. Intervention centers not just on protecting potential victims (Red Flag), but also presenting an alternative cultural vision by condemning and opposing the violence (Green Dot).

While the early movements created hotlines, today the movement is web based. The internet and social media has opened a new space for these movements, as evidenced by the \#YESALLWOMEN Twitter campaign and Facebook's Yes All Women site which were created after the mass murders committed by a young man in California who blamed women for his failure to get a girlfriend. ${ }^{84}$ While these particular campaigns are clearly twenty-first century since they center on personal narratives, they have the potential to politicize the issue in the same way that consciousness-raising did in the 1960s and 70 s. In combination with the calls for social and cultural transformation, as well as policy changes at colleges, these narratives move the personal toward the political. These calls for justice for victims and social transformation of the rape culture, however, are not through music. At least, not yet.

The movements have not relied on music in a way that the Labor and Civil Rights Movements did by utilizing the music to inspire and mobilize its members. As Eyerman and Jamison suggest, the music, through exemplary actors and actions, has served mostly to maintain the movements while it lacked visible leaders and organization and to prepare for the emergence of a new movement. While the recent music has not been as exemplary as the earlier music, it shows that rape and domestic violence remained an issue to be dealt with politically and culturally and this new movement suggests that the time has come to once again aggressively address these problems. This opens a space for the music to become more exemplary and more political.

\section{Age, Race, Class, and the Women Singer-Songwriters}

Since the women singer-songwriters explored here differ in age, race, class and sexual orientation, some consideration should be given to the way these characteristics have shaped their positions as

\footnotetext{
${ }^{79}$ Bill Pennington and Steve Eder, "In Domestic Violence Cases, NFL Has a History of Lenience," New York Times online edition, September 19, 2014; Associated Press, "Saban Dismisses Taylor From Team After Arrest," New York Times, March 29, 2015.

${ }^{80}$ Wendy Joan Biddlecombe, “College Sexual Assault Movement Gaining Momentum in New York,” Metro, October 30, 2014; Schwartz, Jess. "Florida State Students Protest Rape Culture.” Fight Back! News, April 15, 2013.

${ }^{81} \mathrm{http}: / /$ www.theredflagcampaign.org/index.php/about/about-the-campaign/.

${ }^{82} \mathrm{http}: / /$ itsonus.org/.

83 http://livethegreendot.com/.

${ }^{84}$ Emily Bland, “\#YesAllWomen Hits Campus," fsunews.com, June 4, 2014, accessed 2 April 2015, http://archive.fsunews.com/article/20140604/FSVIEW0101/140604007/-YesAllWomen-movement-hits-campus.
} 
exemplary actors. Mitchell, the oldest of these women, is in her 70s. Lady Gaga is the youngest, having just reached her 30s. Chapman and Amos are in their 50s and DiFranco in her 40s. Only Chapman is black, lesbian, and from a poor background. The others have backgrounds that would be considered middle to upper middle class. Amos and Lady Gaga have publicly identified as rape survivors. Despite their differences, each of these women have served as exemplary actors, maintaining and expanding the values and ideals of the anti-rape and domestic violence movements.

Mitchell's approach to rape and domestic violence are much more generalized than the others. Perhaps one explanation for this may be that she is closest to Eyerman and Jamison's Bohemian artist who views the dominant culture as too limiting to her artistic expression. Her early works are mostly about her loves and relationships and she was best known for her unusual and creative guitar tunings. Unlike other singer-songwriters, she was also constantly experimenting with new genres, moving from folk, to folk rock, to rock and jazz. Commercially, she paid a price for this experimentation, but it was never the success that mattered to her, it was the art. She also, to this day, sees herself as a painter first and a singersongwriter second. It was not until her late 30 s and early 40 s that she really began to see the politics of the world around her and incorporate it into her music. Yet, it is not surprising that she eventually reached that point since many of the men she associated with in the late 1960s and early 1970s, in particular, Graham Nash of Crosby, Stills \& Nash, and her fellow Canadian, Neil Young, were certainly writing songs about political issues while she lived with them as well as to this day. While she did give up her daughter for adoption because she was still a struggling artist and her husband had expressed dismay at her pregnancy, there is no public evidence that Mitchell had personally experienced rape or domestic violence. Thus, while she addresses love and loss in a very personal way in her music, her presentation of the issues of rape and domestic violence is much less personal.

As a black lesbian from poor beginnings, Tracy Chapman's identity is very different from the other singer-songwriters considered. As a black woman, she is one of only two commercially successful black women in the musical genre of folk rock, the other being Joan Armatrading. As a lesbian, she shares this identity with Indigo Girls, Amy Ray and Emily Saliers, as lesbian musicians of the genre. Like Indigo Girls, in few, if any, of her songs does Chapman identify the gender of the characters she is addressing or describing. Interestingly, the song "For My Lover" can be interpreted as being about either a gay or lesbian relationship or an interracial relationship (though I suspect the latter as the reference to a Virginia jail hints the song may be about the Lovings, who successfully challenged Virginia's ban in interracial marriage at the Supreme Court).

Yet, even though Chapman was able to escape her humble beginnings by attending an elite prep school and Tufts University, it is clear in her music that her race and early poverty play an important part in her music. She has multiple songs that address human rights and injustice, war and violence, and the need for change, especially on her first two albums. This is also clear in her work on behalf of social justice groups and her establishment of scholarships for poor students. While women's issues are a part of her music and activism, the issues of poverty and racial justice are more common themes for Chapman. Even in "Behind the Wall," there is a sense that the woman being abused is probably poor since she lives in an apartment with thin walls and the police are reluctant to respond, perhaps not just because it is domestic violence but because it is a minority neighborhood. Unlike Mitchell, Chapman's music dealing with domestic violence is very personal, perhaps because she had a more intimate relationship with the experience than Mitchell.

Tori Amos, who is white and from a middle-class background, is in her 50s. She was young when 
the women's movement re-ignited in the 1960s and 70s, but she openly identifies as feminist, herself referring to the album American Doll Posse as a feminist album. DiFranco, also white and middle class, is only seven years younger than Amos, and she too is outwardly feminist. These two women have written the most songs about rape and domestic violence, and while Amos has stated that her song "Me and a Gun" is about her rape experience, it seems likely that DiFranco's songs on these topics come from personal experience as well. This personal connection mixed with their strong feminism, rooted in the Second Wave, has produced very exemplary music.

Lady Gaga is the youngest of the women and she is solidly ensconced in the Third Wave. She also appears to come from the most privileged background, having grown up on the Upper West Side of Manhattan. Mitchell, Chapman, Amos and DiFranco's performances are usually simple, with their major props being their instruments, either the guitar or piano. Lady Gaga, on the other hand, is known for her interesting fashion choices and her shows are spectacular theatrical productions, although she is previewing her new album in small venues. Lady Gaga's self-presentation is intended to get media attention and she always succeeds in getting that attention. Indeed, she has been a driving force in feminist cultural production over the last decade. She has also been able to showcase her politics on a wide stage. Her song "Til It Happens to You" was co-written for a documentary about sexual assault on college campuses and performed at the Oscars award ceremony, thus giving her a much larger audience than the others would likely ever have had. Her song "Swine" also reflects the anger of many young Third Wave women because they feel they are still being denied the respect and freedoms they are entitled to receive. Since this song is about a personal experience, it addresses the issue of rape in a more intimate way, though the need for context to understand the politics of the song makes it less exemplary than Amos' "Me and a Gun” and DiFranco's "Gratitude."

\section{Conclusion}

Eyerman and Jamison have suggested that the relationship between music and political movements is more complex than simply music being a tool for mobilization and inspiration. This research has explored the relationship between music and two movements that did not consciously use it as a tool of mobilization. The evidence suggests that even in the absence of the explicit use of music, these political movements and music have interacted. As the women's movement generally grew and demanded change, some musicians such as John Lennon and Jimi Hendrix repudiated misogynistic songs which portrayed domestic violence as a normal part of relationships. ${ }^{85}$ By the 1990 s, the amount of music dealing with rape and domestic violence as an injustice rather than a normal part of life grew significantly. Of course, the increase in women's voices in popular music alone can account for a substantial increase in such music about rape and domestic violence. As more women experienced success in the music industry, it is not surprising that they wrote and performed songs about their personal experiences involving the violence that was a part of their own and so many women's lives. The women singer-songwriters of the 90s had grown up with vibrant and active anti-rape and anti-domestic violence movements. They came of age at a time when feminist women actively took to the streets protesting the violence. Perhaps they had feminist mothers who had participated in these movements. At the very least, they saw evidence of the movements

\footnotetext{
${ }^{85}$ Lennon repudiated "Run for Your Life," which begins with the line, "Well, I'd rather see you dead, little girl / Than to be with another man," and Hendrix repudiated "Hey, Joe," about a man who kills his girlfriend because he believes she is cheating on him.
} 
in the media and in film. They were being educated by the movements about the extent of the violence and the myths surrounding them and in turn became exemplary actors for the movements even as the movements lost media coverage.

The decline of exemplary actors in the twenty-first century is more complex. As feminism shifted away from politics to personal narratives, so did the music. This may be one explanation for the change. The personal narratives of twenty-first century feminism lack any theoretical critique of the dominant ideology, i.e., "rape culture." Prior to the recent rise of the new movements that are concerned with social and cultural transformation, the twenty-first century music consists either of non-contextualized/depoliticized storytelling or focuses on anger at the injustice of violence against women without presenting an alternative vision. Another possible factor is that most of the pop and rock stars who have addressed these topics are products of the twenty-first century music industry with its emphasis on packaged, sexualized pop stars. Here Lady Gaga is the exception.

This research supports Eyerman and Jamison's claim that the relationship between music and culture and political/social movements is more complex than simply using music to create identity and mobilize members of the movements. It has also shown the importance of exemplary actors to the movements. The movements can influence the content of the music and music can be the "political memory" of movements that have waned through lack of organization or leadership and/or bureaucratic capture. As Eyerman and Jamison suggest, the study of political movements could benefit from a greater understanding of the relationship between politics and culture.

\section{References}

Ali, Russlyn. "Dear Colleague Letter: Sexual Violence." U. S. Department of Education Office of Civil Rights. April 4, 2011. https:/www.whitehouse.gov/sites/default/files/dear_colleague_sexual_violence.pdf.

Amos, Tori. Piece by Piece. New York: Broadway Books, 2005.

Ankeny, Jason. “Ani DiFranco: Biography.” MSN Entertainment. Accessed November 5, 2011. http://music.msn.com/music/artist/biography/anidifranco/?silentchk=1\&wa=wsignin.10.

Associated Press. "Saban Dismisses Taylor From Team After Arrest." New York Times, March 29, 2015. Accessed 2 April 2015. http://www.nytimes.com/aponline/2015/03/29/sports/ncaafootball/ap-fbcalabama-taylor-arrested.html.

Bachman, Ronet, and Raymond Paternoster. "A Contemporary Look at the Effects of Rape Law Reform: How Far Have We Really Come?” The Journal of Criminal Law and Criminology (1973-) 84, no. 3 (1993): 554-74.

Bevacqua, Maria. Rape on the Public Agenda: Feminism and the Politics of Sexual Assault. Boston: Northeastern University Press, 2000.

Biddlecombe, Wendy Joan. "College Sexual Assault Movement Gaining Momentum in New York." Metro, October 30, 2014. Accessed April 2, 2015. http://www.metro.us/new-york/college-sexual-assaultmovement-gaining-momentum-in-new-york/zsJnjC---jy6gBZLcivs/.

"Biography." About Tracy Chapman. http://www.about-tracy-chapman.net/.

Bland, Emily. “\#YesAllWomen Hits Campus.” fsunews.com, June 4, 2014. Accessed 2 April 2015. http://archive.fsunews.com/article/20140604/FSVIEW0101/140604007/-YesAllWomen-movementhits-campus. 
Clery Center. "Summary of the Jeanne Clery Act." Accessed June 24, 2016.

https://clerycenter.org/summary-jeanne-clery-act.

Davis, Angela Y. Blues Legacies and Black Feminism: Gertrude "Ma" Rainey, Bessie Smith and Billie Holiday. New York: Vintage Books, 1998.

Davis, Richard. "Understanding Domestic Violence: Dual Arrests and the Domestic Violence Arrests of Women.” Policeone.com, April 8, 2005. Accessed March 13, 2013.

http://www.policeone.com/standoff/articles/98522-Dual-arrests-and-the-domestic-violence-arrestsof-women/.

Dixon, Travis L., Yuanyuan Zhang, and Kate Conrad. "Self-Esteem, Misogyny and Afrocentricity: An Examination of the Relationship between Rap Music Consumption and African American Perceptions." Group Processes \& Intergroup Relations 12, no. 3 (2009): 345-60. https://doi.org/10.1177/1368430209102847.

Eyerman, Ron, and Andrew Jamison. Music and Social Movements: Mobilizing Traditions in the Twentieth Century. Cambridge: Cambridge University Press, 1998. https://doi.org/10.1017/CBO9780511628139.

Farley, Melissa, and Howard Barkan. "Prostitution, Violence Against Women, and Posttraumatic Stress Disorder." Women E Health 27, no. 3 (1998): 37-49. https://doi.org/10.1300/J013v27n03 03.

Feng, Violet. "The Magdalene Laundries.” CBS News, August 8, 2003. Accessed November 14, 2011. http://www.cbsnews.com/stories/2003/08/08/sunday/main567365.shtml.

"Forcible Rape." FBI. August 17, 2012. http://www.fbi.gov/about-us/cjis/ucr/crime-in-the-u.s/2011/crimein-the-u.s.-2011/violent-crime/forcible-rape.

Gourdine, Ruby M., and Brianna P. Lemmons. "Perceptions of Misogyny in Hip Hop and Rap: What Do the Youths Think?" Journal of Human Behavior in the Social Environment 21, no. 1 (2011): 57-72. https://doi.org/10.1080/10911359.2011.533576.

Graff, Gary. "Joni Mitchell Looks at the Darker Side." Detroit Free Press, October 23, 1994, archived on jonimitchell.com. Accessed November 14, 2011. http://jonimitchell.com/library/view.cfm?id=971.

Gribi, Gerri. CreativeFolk.com. http://creativefolk.com/.

Herman, Judith Lewis. Trauma and Recovery: The Aftermath of Violence-From Domestic Abuse to Political Terror. New York: Basic Books, 1992.

Hiatt, Brian. "Deep Inside the Unreal World of Lady Gaga.” Rolling Stone online, June 9, 2011. http://www.rollingstone.com/music/news/deep-inside-the-unreal-world-of-lady-gaga-20110609.

Hirschel, David. "Making Arrests in Domestic Violence Cases: What Police Should Know." National Institute of Justice: IN Short: Toward Criminal Justice Solutions (2009). Accessed October 10, 2011. http://www.ncjrs.gov/pdffiles1/nij/225458.pdf.

Hirschel, David, Eve Buzawa, April Pattavina, and Don Faggiani. "Domestic Violence and Mandatory Arrest Laws: To What Extent Do They Influence Police Arrest Decisions?” The Journal of Criminal Law and Criminology (1973-) 98, no.1 (2007): 255-98.

Hewitt, Nancy A. "Feminist Frequencies: Regenerating the Wave Metaphor." Feminist Studies 38, no. 3 (2012): 658-80.

Jenson, Lisa. “The Cycle of Domestic Violence and Barriers to Treatment.” The Nurse Practitioner 25, no. 5 (2000): 26-29.

Jimi Hendrix: Voodoo Child. Directed by Bob Smeaton. Biography Channel, 2010. 
Keyes, Cheryl L. "Empowering Self, Making Choices, Creating Spaces: Black Female Identity via Rap Music Performance." The Journal of American Folklore 113, no. 449 (Summer 2000): 255-69. https://doi.org/10.2307/542102.

Kinser, Amber E. "Negotiating Spaces for/through Third Wave Feminism.” NWSA Journal 16, no. 3 (2004): 124-53. https://doi.org/10.2979/NWS.2004.16.3.124.

Koss, Mary P., Lisa A. Goodman, Angela Browne, Louise F. Fitzgerald, Gwendolyn Puryear Keita, and Nancy F. Russo. No Safe Haven: Male Violence Against Women at Home, at Work, and in the Community. Washington, D.C.: American Psychological Association, 1994. https://doi.org/10.1037/10156-000.

"Lady Gaga Biography.” Rolling Stone online. http:/www.rollingstone.com/music/artists/ladygaga/biography.

MacDonald, Ian. Revolution in the Head: The Beatles' Records and the Sixties, 2nd ed. London: Pimlico (Rand), 2005.

McDonald, Soraya Nadia. "Lady Gaga reveals that she was raped by a record producer when she was 19." Washington Post online edition, December 3, 2014. Accessed March 30, 2015. http://www.washingtonpost.com/news/morning-mix/wp/2014/12/03/lady-gaga-reveals-that-she-wasraped-by-a-record-producer-when-she-was-19/.

MacKinnon, Catherine. Women's Lives, Men's Law. Cambridge, MA: Harvard University Press, 2005.

Markon, Jerry. "Justice Department Expands Definition of Rape to Include Other Forms of Sexual Assault.” Washington Post online edition, January 6, 2012. Accessed June 24, 2016. https://www.washingtonpost.com/politics/justice-dept-expands-definition-of-rape-to-include-otherforms-of-sexual-assault/2012/01/06/gIQAbM7CfP_story.html.

Molotsky, Irvin. “Admiral Has to Quit Over His Comments on Okinawa Rape.” New York Times online edition, November 18, 1995. Accessed November 14, 2011.

http://www.nytimes.com/1995/11/18/world/admiral-has-to-quit-over-his-comments-on-okinawarape.html.

Newman, Jason. "Elton John, Lady Gaga Nominated for GLAAD Media Awards.” Rolling Stone online, January 20, 2014. Accessed June 27, 2016. http://www.rollingstone.com/music/news/elton-johnlady-gaga-nominated-for-glaad-media-awards-20140130.

Pennington, Bill, and Steve Eder. "In Domestic Violence Cases, NFL Has a History of Lenience." New York Times online edition, September 19, 2014. Accessed April 2, 2015.

http://www.nytimes.com/2014/09/20/sports/football/in-domestic-violence-cases-nfl-has-a-historyof-lenience.html.

National Coalition Against Domestic Violence. Domestic Violence Facts. 2007. Accessed 10 October 2011. http://www.ncadv.org/files/DomesticViolenceFactSheet(National).pdf.

Parker, Ashley. "House Renews Violence Against Women Measure.” New York Times online edition, February 28, 2013. Accessed March 13, 2013. http://www.nytimes.com/2013/03/01/us/politics/congress-passes-reauthorization-of-violenceagainst-women-act.html.

Poey, Delia. "Striking Back without Missing a Beat: Radical Responses to Domestic Violence in Country Music's The Dixie Chicks and Salsa's Celia Cruz." Studies in Popular Culture 32, no. 2 (2010): 1-15.

Rape Abuse and Incest National Network (RAINN). "Statistics." Statistics |RAINN. Accessed October 7, 2011. http://www.rainn.org/statistics.

. “Mission Statement.” RAINN. Accessed October 31, 2011. http://www.rainn.org/aboutrainn/mission-statement. 
. "A Crime Without Consequence." RAINN. Accessed March 13, 2013.

http://www.rainn.org/news-room/news/reporting-and-prosecution-of-rape-cases.

. "Scope of the Problem." Statistics | RAINN. Accessed April 1, 2015. https://www.rainn.org/getinformation/statistics/frequency-of-sexual-assault.

Reid-Brinkley, Shanara R. “The Essence of Res(ex)pectability: Black Women's Negotiation of Black Femininity in Rap Music and Music Video. Meridians: Feminism, Race, Transnationalism 8, no. 1 (2008): 236-60. https://doi.org/10.2979/MER.2008.8.1.236.

Rybaczewski, Dave. "Run for Your Life." Beatles Music History. Accessed October 18, 2011. Toledo, OH: DKR Products. http://www.beatlesebooks.com/run-for-your-life.

Sacco, Lisa N. "The Violence Against Women Act: Overview, Legislation and Federal Funding." Congressional Research Service. Accessed June 24, 2016. https://www.fas.org/sgp/crs/misc/R42499.pdf.

Schuppe, John. "Vice President Joe Biden to Stanford Rape Victim: You are a Warrior." NBC News online, June 9, 2016. Accessed June 27, 2016. http://www.nbcnews.com/news/us-news/you-are-warriorbiden-pens-open-letter-stanford-rape-victim-n589151.

Shanley, Mary Lyndon. Women's Rights, Feminism, and Politics in the United States. Washington, D.C.: American Political Science Association, 1988.

SafeNetwork: California's Domestic Violence Resource. Herstory of Domestic Violence: A Timeline of the Battered Women's Movement, published by Minnesota Center Against Violence and Abuse, 1999. Accessed October 10, 2011. http://www.mincava.umn.edu/documents/herstory/herstory.html.

Savage, Charlie. "US to Expand its Definition of Rape in Statistics." New York Times online edition, January 6, 2012. http://www.nytimes.com/2012/01/07/us/politics/federal-crime-statistics-to-expandrape-definition.html.

Schechter, Susan. Women and Male Violence: The Vision and Struggles of the Battered Women's Movement. Boston: South End Press, 1982.

Schwartz, Jess. "Florida State Students Protest Rape Culture." Fight Back! News, April 15, 2013. http://www.fightbacknews.org/2013/4/15/florida-state-students-protest-rape-culture.

Simon, Sheila. "Greatest Hits: Domestic Violence in American Country Music." Oregon Law Review 82 (2003): 1107-23.

Snyder, R. Clair. "What is Third Wave Feminism? A New Directions Essay." Signs 34, no. 1 (2008): 17596. https://doi.org/10.1086/588436.

Thompson, Dave. "He Hit Me (And It Felt Like a Kiss)": Song Review. allmusic. Accessed 18 October 2011. Ann Arbor: Rovi Corporation. http://www.allmusic.com/song/t1072015.

“Tracy Chapman—Official Website.” TracyChapman.com. Accessed July 08, 2017. http://www.tracychapman.com/.

Toriamos.com. "Sexual Healing." Harp. August 2007. Accessed October 31, 2011. http://toriamos.com/go/galleries/view/993/1/992/press/index.html.

Tong, Rosemarie. Feminist Thought: A More Comprehensive Introduction. 3rd ed. Boulder, CO: Westview Press, 2009.

Weitzer, Ronald, and Charis E. Kubrin. "Misogyny in Rap Music: A Content Analysis of Prevalence and Meanings." Men and Masculinities 12, no. 1 (2009): 3-29. https://doi.org/10.1177/1097184X08327696.

WhiteHouse.gov. "Factsheet: The Violence Against Women Act.” Accessed March 30, 2015. https://www.whitehouse.gov/sites/default/files/docs/vawa_factsheet.pdf. 
Whitesell, Lloyd. The Music of Joni Mitchell. Oxford: Oxford University Press, 2008. https://doi.org/10.1093/acprof:oso/9780195307993.001.0001.

Yoffe, Emily. "The Hunting Ground: The Failure of a New Documentary About Rape on College Campuses." Slate.com, February 27, 2015.

http://www.slate.com/articles/double x/doublex/2015/02/the hunting ground_a_campus rape_docu mentary_that_fails_to_provide_a_full.html

\begin{abstract}
This research utilizes Eyerman and Jamison's concept of exemplary action/actors to explore the relationship between the anti-rape or anti-domestic violence movements and music dealing with rape and domestic violence by five women singer-songwriters. Neither movement relied upon music as a source of identity, solidarity, or mobilization, yet their existence opened a space for women singer-songwriters to empower, educate and raise the consciousness of women and men-that is, to engage in exemplary actions around the issues of rape and domestic violence. Though the movements were transformed through bureaucratic demands, losing their radical political mission, artists still used this space to express the ideas, values and goals of the movements to a new generation. As the women's movement evolved, the messages in the music kept the issues alive but with a different focus. The liberal and radical ideas of the early movement were replaced by the Third Wave's emphasis on cultural production, diversity, and personal narrative.
\end{abstract}

